\title{
ISPITIVANJE AKTUALNIH TRENDOVA U KORIŠTENJU DRUŠTVENIM MREŽAMA KOD UČENIKA PRVOG I TREĆEG RAZREDA SREDNJIH ŠKOLA U HRVATSKOJ
}

\author{
Gordana Buljan Flander \\ Ella Selak Bagarić \\ Krešimir Prijatelj \\ Mirna Čagalj Farkas \\ Poliklinika za zaštitu djece i mladih Grada Zagreba \\ $\checkmark$ E-mail:mirna.farkas@poliklinika-djeca.hr
}

\begin{abstract}
SAŽETAK
Budući da danas odrastanje gotovo neizostavno uključuje i svakodnevnu uporabu modernih tehnologija, važno je ispitati na koji način i u kojem vremenskom okviru mladi provode vrijeme na internetu i društvenim mrežama. Cilj provedenog istraživanja bio je ispitati opće navike korištenja internetom i društvenim mrežama kod adolescenata srednjoškolske dobi u Republici Hrvatskoj ( $\mathrm{N}=1806)$. Online upitnikom, konstruiranim za potrebe ovog istraživanja putem Google Forms platforme, ispitana je nekolicina čimbenika provođenja vremena na internetu i društvenim mrežama. U rezultatima su detaljno izložene aktivnosti adolescenata po pojedinim društvenim mrežama, kao i čimbenici povezani s adolescentima u kontekstu mrežnih aktivnosti. Rezultati upozoravaju da se tijekom vremena mijenjaju preferencije korištenja društvenim mrežama kod adolescenata, ali i upućuju na sklonost upuštanja mladih u rizična ponašanja poput upoznavanja ili dopisivanja s nepoznatim osobama. Navedeno upozorava na potrebu za kontinuiranom doedukacijom stručnjaka, ali i roditelja, koja će pratiti navike djece i mladih, kao i implementaciju strukturiranih modaliteta rada s djecom i mladima o sigurnom korištenju internetom.

Ključne riječi: društvene mreže, internet, adolescenti, navike, elektronički uređaji
\end{abstract}

\section{UVOD}

Internet i društvene mreže postali su svakodnevica odraslih, ali i adolescenata koji im se okreću kada traže informacije, žele naučiti nešto novo ili komunicirati s drugima. Zahvaljujući raširenosti pametnih telefona, većina se adolescenata gotovo stalno koristi internetom, odnosno 90\% njih kaže da idu na internet barem nekoliko puta u danu (Anderson i Jiang, 2018 ${ }^{\text {b }}$. U 2012. godini prvi je put zabilježeno veće korištenje internetom nego računalom - što je reflektiralo porastom korištenja alternativnim uređajima poput mobitela i tzv. pametnih mobitela (engl. smartphones) (Eurostat, 2020). Državi zavod za statistiku Republike Hrvatske (2019) ističe da je u Hrvatskoj uporaba mobilnoga širokopojasnog pristupa internetu u 2019. godini porasla za $4 \%$ u 
odnosu na prethodnu godinu. U začetcima istraživanja navika korištenja društvenim mrežama, interes je najviše bio usmjeren na Facebook, tada najpopularniju društvenu mrežu (Yonker, Zan, Scirica, Jethwani i Kinane, 2015). Ipak, korištenje društvenim mrežama kod mladih se posljednjih godina promijenilo, a i dalje se sve brže mijenja. Veliko istraživanje na reprezentativnom uzorku adolescenata u dobi od 13 do 17 godina u SAD-u pokazalo je da su se adolescenti s Facebooka prebacili na mreže poput Instagrama i Snapchata koje im nude novije i različitije načine korištenja te izražavanja u obliku fotografija i videa (NORC at the University of Chicago, 2017), što pokazuju i istraživanja u Europi (Smahel, Machackova, Mascheroni, Dedkova, Staksrud, Ólafsson, Livingstone i Hasebrink, 2020). Recentnija istraživanja upućuju na sve veću popularnost drugih platformi kod adolescenata, od kojih se uz navedeni Snapchat i Instagram najviše ističe YouTube (Anderson i Jiang, 2018a). Uz to, danas je uobičajeno da se mladi koriste $s$ više različitih platformi umjesto jedne dominantne (Anderson i Jiang, 2018b). Također, većina adolescenata u novije vrijeme počela se koristiti aplikacijama za dopisivanje da bi komunicirala s drugima (NORC at the University of Chicago, 2017). Eurostat (2019) navodi da među mlađom populacijom (između 16 i 24 godine) oko $88 \%$ mladih sudjeluje na društvenim mrežama, dok za Hrvatsku postotak mladih uključenih u društvene mreže iznosi $97 \%$. Iskustva stručnjaka, kao i istraživačka praksa u Hrvatskoj, usuglašeni su s većinom europskih, odnosno svjetskih istraživanja. Primjerice, ranije istraživanje provedeno na hrvatskom uzorku iz 2010. godine pokazalo je da Facebook profil posjeduje $89,1 \%$ učenika viših razreda osnovnih škola, a od drugih online društvenih mreža, tek mali postotak koristio se drugim mrežama, odnosno 23,2\% učenika koristilo se MySpaceom, a 15,9\% učenika Twitterom (Kušić, 2010). Navedeno istraživanje pokazalo je i da se čak 29,3\% učenika viših razreda osnovnih škola uopće ne koristi nekom drugom online društvenom mrežom ili alatom za komunikaciju s prijateljima (Kušić, 2010). U Hrvatskoj su 2017. godine autori Ciboci, Ćosić Pregrad, Kanižaj, Potočnik i Vinković na reprezentativnom uzorku djece ispitali njihove digitalne navike. Pokazalo se da većina djece u dobi od 9 do 17 godina ima mogućnost pristupanja internetu, kao i da većina njih posjeduje mobitel, pametni telefon, računalo ili neki drugi uređaj pomoću kojega mogu pristupiti internetu kada im je to potrebno (Ciboci i sur., 2020). Također, dobiveno je da su najpopularnije društvene mreže među učenicima šestih i sedmih razreda osnovnih škola Facebook (74\%) i Instagram (63\%), dok se stariji adolescenti u dobnoj skupini od 15 do 17 godina najviše koriste Facebookom, zatim YouTubeom, Instagramom, Viberom pa WhatsAppom (Ciboci i sur., 2020). Među ostalim mrežama, koje se spominju u istraživanjima, navodi se da se djeca još koriste Snapchatom, ASKfmom, Vineom, Skypeom i Tumblrom (Rattinger, 2017).

Nadalje, djeca i mladi su s godinama sve aktivniji na društvenim mrežama, odnosno stariji adolescenti češće se koriste društvenim mrežama i imaju profile na većem broju platformi (NORC at the University of Chicago, 2017), što je pokazano i na hrvatskom uzorku (Ciboci i sur., 2020). Prema istraživanju učenika viših razreda osnovnih škola (Rattinger, 2017), osim što se koriste različitim društvenim mrežama, čak 42\% djece provjerava ih nekoliko puta dnevno, a 23\% kažu da su uključeni neprestano. Uz to, dnevno u tim aktivnostima provode najčešće do sat ili dva dnevno, a čak $24 \%$ učenika na društvenim mrežama provode tri, četiri ili više sati (Rattinger, 2017). Metaanalizom 27 studija, Vanucci, Simpson, Gagnon i McCauley Ohannessian (2020) utvrdili su određene povezanosti među većom količinom korištenja društvenim mrežama i rizičnim ponašanjem (uključujući uporabu psihoaktivnih supstanci i rizičnih seksualnih ponašanja). Uporaba društvenih mreža također je povezana i sa seksualnošću adolescenata, njihovim odnosima s vršnjacima te s većom sklonošću 
upuštanja u rizična ponašanja (Eleuteri, Saladino i Verrastro, 2017). Nakon saznanja o tome koliko vremena adolescenti provode na društvenim mrežama, ali i potencijalnim opasnostima istih, interes istraživača bio je usmjeren na to kako mladi provode vrijeme na internetu, odnosno društvenim mrežama, odnosno u kojim aktivnostima. Od aktivnosti koje nužno ne uključuju komunikaciju s drugima, najzastupljenije je bilo slušanje glazbe, potom korištenje internetom za zadaću i učenje, gledanje videouradaka i igranje igara na internetu (Ciboci i sur., 2020). Važno je napomenuti da se trendovi u korištenju društvenim mrežama značajno mijenjaju, naročito u posljednjih nekoliko godina. Naime, od provođenja ovog istraživanja, u svijetu pa tako i Hrvatskoj, među mladima je postala popularna mreža TikTok (Nesi, 2020). Dinamičnost tog područja razvidna je i u činjenici da je Snapchat bio vrlo popularan prije nekoliko godina, a danas u praksi imamo prilike čuti da se njime nešto manje koriste i djeca i mladi. Dakle, cilj je konkretnog istraživanja ispitati općenite navike korištenja internetom i društvenim mrežama kod adolescenata srednjoškolske dobi u Republici Hrvatskoj.

\section{METODA}

Društvena 'online' iskustva i mentalno zdravlje mladih naziv je širega nacionalnog istraživačkog projekta koji je u razdoblju od studenoga 2018. do listopada 2019. provodila Poliklinika za zaštitu djece i mladih Grada Zagreba u suradnji s Gradskim uredom za zdravstvo Grada Zagreba i Društvom za komunikacijsku i medijsku kulturu. Projekt je uključivao mlade srednjoškolske dobi, a obuhvaćao je ispitivanje nekih stavova, emocija i ponašanja na internetu (a naročito na društvenim mrežama).

\section{Sudionici}

Uzorak je učinjen na temelju uvida u pedagoške standarde o broju učenika u srednjim školama i Državnog zavoda za statistiku za kraj školske godine 2016./2017., odnosno za početak školske godine 2017./2018., koji su bili najrecentniji i trenutno dostupni prilikom procesa uzorkovanja. Iz uzorka su izostavljene srednje škole za mladež s teškoćama u razvoju, srednje umjetničke (glazbene i plesne) te škole za obrazovanje odraslih. Sve 24 škole odazvale su se istraživanju, kao i učenici unutar razreda navedenih škola. Istraživanje se provodilo u pet hrvatskih gradova, a to su Zagreb, Split, Rijeka, Osijek i Dubrovnik. Online upitnik ispunilo je 1838 adolescenata, od čega je njih 44 isključeno iz statističke obrade zbog sumnje u valjanost njihovih odgovora na temelju odgovora koje su davali na pitanja otvorenog tipa (vulgarni odgovori, šaljivi odgovori koji nisu povezani s pitanjem i dr.) ili na temelju nemogućih odgovora na varijablu dobi. Na uzorku od 1794 adolescenata prvih i trećih razreda srednjih škola koji su ispunjavali online upitnik, 703 sudionika (39,2\%) izjašnjava se da je muškog spola, 1075 (59,9\%) izjašnjava se da je ženskog spola, dok se 16 sudionika (1\%) izjašnjava ostalim odgovorima. Jedna se osoba izjašnjava kao transseksualna te jedna kao hermafrodit, ali u odgovorima na pitanje o spolu na Beckovim inventarima izostaju takvi odgovori. Na Beckovim inventarima 767 sudionika (41,2\%) izjašnjava se kao muško te 1095 (58,8\%) kao žensko. Dob u uzorku kreće se od 14 do 19 godina., dok su ostali odgovori nemogući (npr. 1 godina, 125 godina). Uzimajući u obzir moguće odgovore, prosječna dob je 16,1 godina uz standardnu devijaciju 1,14 godina. 
Prvi razred srednje škole pohađa 918 sudionika (51,2\%), dok treći razred srednje škole pohađa 876 sudionika (48,8\%). U gimnaziju je upisano 725 sudionika (40,4\%), dok je u strukovnu srednju školu upisano 1069 sudionika (59,9\%). Prema socioekonomskom statusu, 13 sudionika $(0,7 \%)$ je izrazito ispodprosječno, 71 (4\%) ispodprosječno, 1059 (59\%) prosječno, $602(33,6 \%)$ iznadprosječno te 49 (2,7\%) izrazito iznadprosječno. Prema veličini mjesta, 257 sudionika (14,3\%) dolazi iz mjesta s manje od 2000 stanovnika, 308 sudionika (17,2\%) iz mjesta s 2000 - 10000 stanovnika, 380 sudionika (21,2\%) iz mjesta s 10000 - 100000 stanovnika, 401 sudionik (22,4\%) iz mjesta sa 100 000 - 500000 stanovnika te 448 sudionika (25\%) iz mjesta s više od 500000 stanovnika.

Prema spolnoj orijentaciji, 1469 sudionika $(81,9 \%)$ je heteroseksualno, 24 sudionika $(1,3 \%)$ je homoseksualno, 66 sudionika (3,7\%) je biseksualno, 3 sudionika (0,2\%) je aseksualno, njih 213 $(11,9 \%)$ ne želi se izjasniti, dok se preostali odgovori odnose na ostale seksualne orijentacije (pansexual, queer i slično).

\section{Instrumentarij}

Online upitnik bio je sastavljen od nekolicine pojedinačno grupiranih pitanja koja su skupno pokrivala korištenje i učestalost korištenja pojedinim društvenim mrežama, uključenost u seksting aktivnosti putem elektroničkih uređaja i moguće emocije do kojih dolazi te neke druge relevantne varijable, koje su detaljnije opisane u daljnjem tekstu. Inicijalno je na temelju pregledane literature odlučeno o korištenju i modifikaciji određenih skala i čestica te osmišljavanju i odabiru onih pitanja koje bi bilo korisno ispitati adolescente u okviru postavljene teme. U konstruiranju upitnika u kontekstu odabira društvenih mreža istraživačima su pomogli i adolescenti koji su navodili društvene mreže kojima se oni i njihovi vršnjaci najčešće koriste. Online upitnik prilagođen je na način da se može ispunjavati online te je stavljen na Google Forms platforme gdje su se svi odgovori i bilježili. Veći dio instrumentarija prilagođen je online ispunjavanju te je stavljen na Google Forms platformu, dok su Beckovi inventari za mlade primijenjeni papir-olovka metodom.

Na početku su sudionicima postavljena pitanja o pristupu internetu (imaju li internet na mobitelima, kod kuće i u školi), nakon čega su uslijedila pitanja o korištenju društvenim mrežama / kanalima / platformama (Facebook [ne uključujući Messenger], Instagram, Snapchat, Viber, WhatsApp, YouTube, Pinterest, Twitter, Vimeo, ASKfm i Messenger) na koja su sudionici označili koriste li se pojedinom društvenom mrežom ili ne. Ako je sudionik odgovorio da se koristi određenom društvenom mrežom, preusmjeren je na pitanje o broju profila na toj mreži, a potom je među ponuđenim prijedlozima trebao označiti jednu preferiranu aktivnost ili dopisati neku drugu opciju (Ponuđene opcije bile su jednake za sve društvene mreže: Dopisujem se s drugima.; Pratim influencere.; Objavljujem različite sadržaje.; Čitam objave prijatelja.; Gledam videosadržaje.; Slušam glazbu.; Igram igre.; ili Čitam vijesti.). Nakon ispitivanja navika korištenja svim društvenim mrežama zasebno, sudionici su na idućem pitanju trebali označiti onu društvenu mrežu / kanal / platformu kojom se najčešće koriste (a ponuđene su bile sve ranije navedene društvene mreže ili su mogli dopisati neku drugu koja nije navedena).

Nakon toga, sudionici su ispunjavali Multidimenzionalni upitnik intenziteta korištenja Facebookom (engl. Multidimensional Facebook Intensity Scale - MFIS; Orosz, Tóth-Király i Bőthe, 2016). Taj se instrument sastoji od 13 čestica koje ispituju intenzitet korištenja društvenom mrežom 
Facebooka, a faktorskom strukturom dobivena su četiri čimbenika: ustrajnost, dosada, pretjerano korištenje i samopredstavljanje.

Navedeni instrument za potrebe toga nacionalnog istraživačkog projekta preveden je metodom "forward and back" na hrvatski jezik i koristio se za ispitivanje intenziteta korištenjem i drugim društvenim mrežama, na način da su sudionici, nakon odabira one društvene mreže kojom se najčešće koriste, bili preusmjereni na pitanja koja izvorno pripadaju Multidimenzionalnom upitniku intenziteta korištenja Facebookom, samo što su pitanja bila univerzalna i oslanjala su se na intenzitet one društvene mreže koju su sudionici izabrali u prethodnom pitanju. Pouzdanost instrumenta procijenjena je Cronbachovim alfa koeficijentom te je bila zadovoljavajuće visoka ( $\alpha=.85$ ).

U narednom setu pitanja provjereni su razlozi korištenja društvenim mrežama, dob prilikom otvaranja prvog profila, društvena mreža na kojoj je otvoren prvi profil i, ako je netko drugi otvorio profil na društvenoj mreži, tko je to bio (Roditelji, Braća ili sestre ili Prijatelji). Neka od pitanja bila su još o procjeni vremena provedenog na društvenim mrežama (Manje od 1 sata, Od 1 do 3 sata, Od 3 do 5 sati, Od 5 do 7 sati, Od 7 do 9 sati ili Više od 9 sati) i čestoći provjeravanja obavijesti / poruka na mobitelu (Stalno, bez obzira je li došla obavijest ili ne; Čim mi dođe obavijest; Nekoliko puta dnevno ili Jednom dnevno ili rjeđe).

Nadalje, sudionike se pitalo jesu li se dopisivali s osobom koju su upoznali putem interneta, mišljenju o tome imaju li više prijatelja online nego uživo, kao i koliko prijatelja, koje su upoznali putem interneta, smatraju pravim prijateljima (Nikoga; Nekoliko njih; Većinu ili Sve). U narednim pitanjima sudionike se pitalo, jesu li upoznali sadašnjeg ili bivšeg partnera/icu putem društvenih mreža te jesu li otišli na susret s osobom koju su upoznali putem društvenih mreža. Sudionike se zatim pitalo o načinu provođenja slobodnog vremena (Na društvenim mrežama / kanalima / platformama za 'online' igranje igara; $U$ druženju s prijateljima uživo; $U$ izvanškolskim aktivnostima (ples, dramska skupina, folklor, učenje jezika, bavljenje glazbom itd.); Bavim se sportom ili dr.) i želji na koji bi način u budućnosti htjeli provoditi slobodno vrijeme (isti ponuđeni odgovori kao i u prethodnom pitanju).

Upitnik općih podataka koji se koristio za potrebe ovog istraživačkog projekta uključivao je varijable spola, dobi, školskog razreda, školskog usmjerenja, seksualne orijentacije, ekonomskog standarda i veličine mjesta ili grada u kojem je sudionik proveo većinu svojeg života.

\section{Postupak}

Kao što je već navedeno, konkretan istraživački projekt proveden je u suradnji Poliklinike za zaštitu djece i mladih s Gradskim uredom za zdravstvo Grada Zagreba i Društvom za komunikacijsku i medijsku kulturu. Nakon što je istraživanje odobrilo Ministarstvo znanosti i obrazovanja, Etičko povjerenstvo Poliklinike za zaštitu djece i mladih Grada Zagreba i Naklada Slap, dozvola za provođenje istog tražena je i od ravnatelja odabranih škola. Samo ispitivanje trajalo je jedan školski sat i uključivalo je kratko predstavljanje istraživačkog projekta i osoba koje ga provode te ustanove iz koje dolaze, davanje uputa sudionicima, dijeljenje testovnog materijala, koji su između ostalog činili i tableti na kojima je postojala prečica za online istraživanje na Google Forms platformi, a samo istraživanje provodili su stručnjaci Poliklinike za zaštitu djece i mladih Grada Zagreba. Ispitivanje se 
sastojalo od dvaju dijelova: prvi dio bio je ispunjavanje Beckovih inventara za mlade (Beck, Beck, Jolly i Steer, 2011; Ružić i Matešić, 2015) koji su jedinstvenim šiframa bili povezani s posebno osmišljenim online upitnikom ostvarenim na Google Forms platformi, koji su mladi ispunjavali putem tableta. Sudionicima je prije sudjelovanja objašnjen istraživački projekt nakon čega su odlučili žele li sudjelovati u istraživanju ili ne. Također, sudionicima je naglašeno da ako se predomisle tijekom ispunjavanja upitnika, u bio kojem trenutku istraživanja mogu odustati od sudjelovanja. Dodatno, na kraju online upitnika navedeni su brojevi Hrabrog telefona i Poliklinike za zaštitu djece i mladih Grada Zagreba kao i e-adrese na koje se sudionici mogu obratiti za podršku ili savjet. Pri dovršetku ispunjavanja upitnika sudionici su upitani za iskustva ispunjavanja upitnika. Ti podatci dio su većeg istraživačkog projekta u kojem nisu korišteni Beckovi inventari za mlade, niti dio pitanja koji se ticao sekstinga među mladima.

\section{REZULTATI}

Rezultati raširenosti uporabe društvenih mreža pokazuju da se najviše sudionika koristi YouTubeom (98\%), zatim Instagramom (92,4\%), WhatsAppom (88,8\%), Snapchatom $(63,2 \%)$, Facebook Messengerom (50,3\%) te Facebookom (42,2\%). Ostale mreže poput Vibera $(27,4 \%)$, Pinteresta (23,6\%), Twittera (13,3\%), Tumblra (6,6\%), ASKfma (0,7\%) te Vimea $(0,4 \%)$ koriste se rjeđe.

Od ostalih društvenih mreža koje su sudionici navodili u slobodnim odgovorima, ističu se Reddit s 41 (2,29\%) korisnikom u uzorku, Discord s 31 (1,72\%) korisnikom, Twitch s 14 (0,78\%) korisnika, Wattpad s $11(0,61 \%)$ korisnika te TikTok s 13 korisnika $(0,72 \%)$ u uzorku.

Najveći broj sudionika ima otvoren po jedan profil na društvenoj mreži. Pregled broja otvorenih profila po mrežama nalazi se u Tablici 1. Najveći nesklad u broju profila vidljiv je na Instagramu, gdje $51,6 \%$ sudionika ima otvoren samo jedan profil, a $32,7 \%$ ih ima otvorena dva profila.

Na YouTubeu se sudionici najčešće bave gledanjem videosadržaja, što je kao najčešću aktivnost navelo 984 sudionika (56\%). Slijedi slušanje glazbe, koje kao najčešću aktivnost navodi 563 sudionika (32\%). Praćenje influencera je kao najčešću aktivnost označilo 168 (9,6\%) sudionika, objavu sadržaja $9(0,5 \%)$ sudionika, čitanje vijesti $9(0,5 \%)$ sudionika, dopisivanje s drugima $6(0,3 \%)$ sudionika, igranje igara $2(0,1 \%)$ sudionika te čitanje objava prijatelja $1(0,1 \%)$ sudionik. Od ostalih se odgovora ništa posebno ne ističe, već sudionici navode vrstu videa koje gledaju na YouTubeu (npr. gledam sport, gledam Fortnite). Na YouTubeu sudionici najčešće gledaju glazbene spotove, što kao najčešći tip gledanog sadržaja navodi 664 sudionika (37,8\%). Slijede ostali videosadržaji, koje kao najčešći tip gledanog sadržaja navodi 471 sudionik (26,8\%). Objave influencera, kao najčešći tip gledanog sadržaja, navodi 362 sudionika (20,6\%), a "gejmere" - prelaženje igrica 261 sudionik (14,8\%). Čak 1677 (95,4\%) sudionika navodi da ništa ne objavljuje na YouTubeu. Najčešće objave tiču se prelaženja igrica - "gejmanja", koje kao najčešći tip objavljivanog sadržaja navodi 31 sudionik (1,8\%). Slijede ostali videosadržaji, koje kao najčešći tip objavljivanog sadržaja navodi 21 sudionik (1,2\%). Glazbene spotove kao najčešći tip objavljivanog sadržaja navodi 16 sudionika $(0,9 \%), 9$ sudionika $(0,5 \%)$ izjavljuje da su influenceri, dok 4 sudionika $(0,2 \%)$ kaže da objavljuje videozapise da bi postali influenceri. 


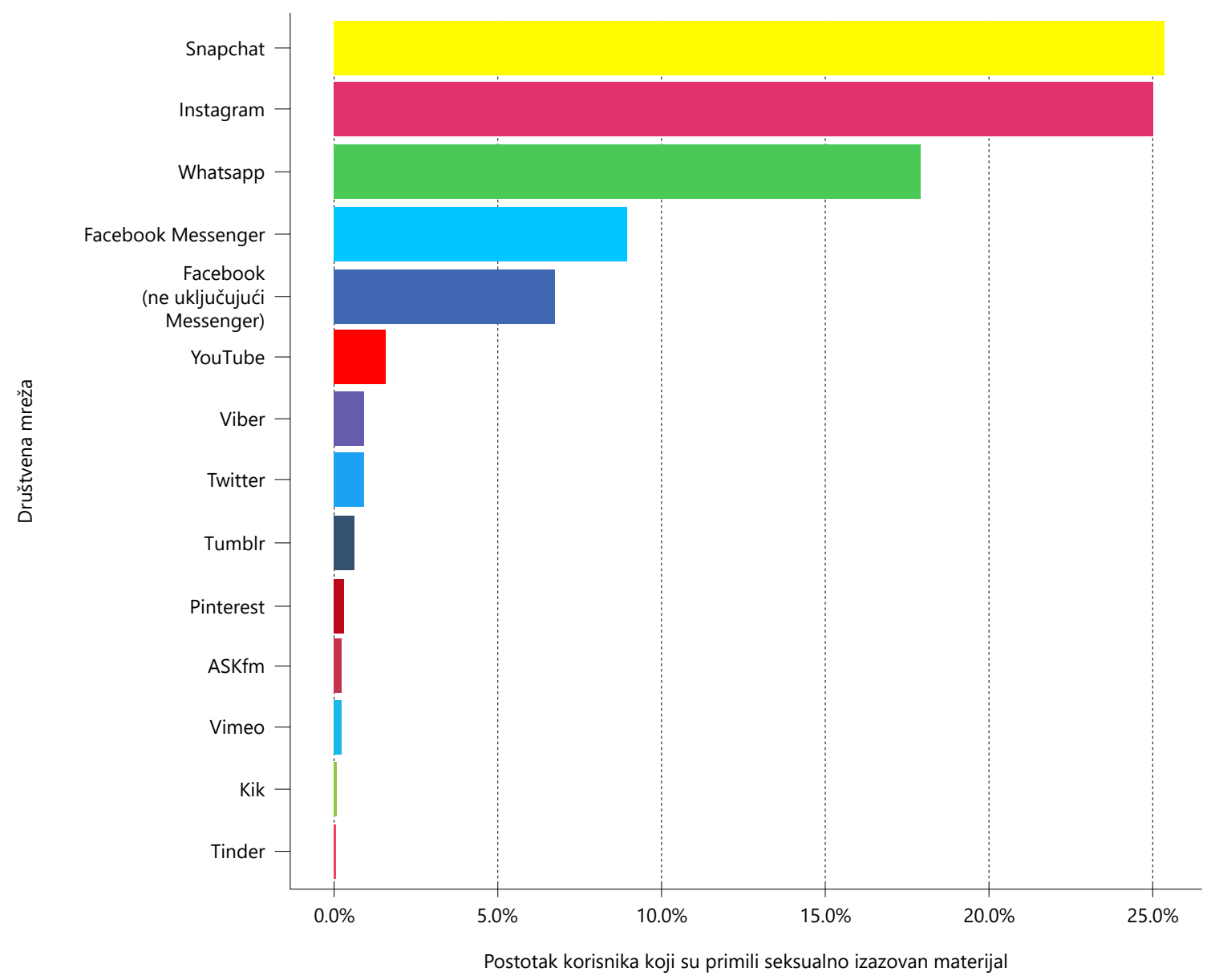

Slika 1. Grafički prikaz raširenosti uporabe društvenih mreža prema broju sudionika koji koriste pojedinu mrežu

Tablica 1. Pregled broja sudionika prema broju otvorenih profila na društvenim mrežama izražen u postotku

\begin{tabular}{|c|c|c|c|c|c|c|}
\hline MREŽA & $\mathbf{N}$ & 1 & 2 & 3 & 4 & $5+$ \\
\hline Facebook & 757 & 88,77 & 7,40 & 1,72 & 0,26 & 1,45 \\
\hline Instagram & 1658 & 51,63 & 32,57 & 9,35 & 3,74 & 2,59 \\
\hline Snapchat & 1134 & 95,15 & 3,35 & 0,62 & & 0,53 \\
\hline Viber & 491 & 98,78 & 0,61 & & & \\
\hline WhatsApp & 1593 & 98,93 & 0,38 & 0,19 & & 0,31 \\
\hline YouTube & 1758 & 77,70 & 7,68 & 2,56 & 0,97 & 1,93 \\
\hline Tumblr & 118 & 88,98 & 7,63 & 0,85 & & \\
\hline Pinterest & 423 & 95,04 & 3,55 & 0,47 & & \\
\hline Twitter & 238 & 82,35 & 13,45 & 2,52 & 0,42 & 0,84 \\
\hline Vimeo & 7 & 71,43 & & & & \\
\hline ASKfm & 13 & 84,62 & 7,69 & & & \\
\hline Facebook Messenger & 903 & 95,68 & 2,66 & 0,78 & & 0,78 \\
\hline
\end{tabular}

$\mathrm{Na}$ Instagramu se sudionici najčešće bave čitanjem objava prijatelja, što je kao najčešću aktivnost označio 481 (29\%) sudionik. Slijedi dopisivanje s drugima, što je navelo 370 (22,3\%) 
sudionika. Gledanje videosadržaja kao najčešću aktivnost navelo je 282 (17\%) sudionika, praćenje influencera $233(14,1 \%)$ sudionika, objavu sadržaja 128 (7,7\%) sudionika, čitanje vijesti 57 (3,4\%) sudionika, slušanje glazbe $8(0,5 \%)$ sudionika te igranje igara $2(0,1 \%)$ sudionika (nagrađivanja, engl. giveaway). Od ostalih odgovora ponovno se ističe gledanje memea (24 sudionika, 1,45\%).

Na WhatsAppu se sudionici najčešće bave dopisivanjem s drugima, što je kao najčešću aktivnost označilo 1573 sudionika (98,7\%). Slijedi objavljivanje različitog sadržaja, praćenje influencera te slušanje glazbe, koje kao najčešće aktivnosti označava 6 sudionika (0,2\%). Igranje igara kao najčešću aktivnost navela su 2 sudionika $(0,1 \%)$, a čitanje vijesti, gledanje videosadržaja i čitanje objava prijatelja po jedan sudionik $(0,1 \%)$. Od ostalih odgovora ističe se uporaba u svrhu školovanja (3 sudionika, 0,2\%), premda neki sudionici navode da se WhatsAppom koriste za prepisivanje testova.

Na Snapchatu se sudionici najčešće bave dopisivanjem s drugima, što je kao najčešću aktivnost označilo 942 (83,1\%) sudionika. Slijedi čitanje objava prijatelja, što su navela 44 (3,9\%) sudionika. Objavu sadržaja navelo je 28 (2,5\%) sudionika, gledanje videosadržaja 24 (2,1\%), praćenje influencera $14(1,2 \%)$, čitanje vijesti $7(0,6 \%)$ sudionika, igranje igara $4(0,3 \%)$ sudionika te slušanje glazbe $1(0,1 \%)$ sudionik. Od ostalih odgovora ističe se skupljanje tzv. vatrica ${ }^{1}$ (engl. Streak/Snapstreak) (17 sudionika, $1,5 \%$ ).

Na Facebook Messengeru sudionici se najčešće bave dopisivanjem s drugima, što kao najčešću aktivnost navodi 864 (95,7\%) sudionika. Slijedi igranje igara, koje kao najčešću aktivnost navodi 21 (2,3\%) sudionik. Čitanje objava prijatelja kao najčešću aktivnost navodi 3 sudionika (0,3\%), praćenje influencera i objavu sadržaja po 2 sudionika $(0,2 \%)$ te slušanje glazbe i čitanje vijesti po jedan sudionik $(0,1 \%)$. Od ostalih se odgovora ništa posebno ne ističe, već se javljaju odgovori poput "Pričam” ili „Slike šaljem sebi".

Najčešća aktivnost kojom se sudionici bave na Facebooku je čitanje vijesti, što je kao najčešću aktivnost označilo 220 (29,1\%) sudionika. Slijedi dopisivanje s drugima, što je navelo 172 (22,7\%) sudionika. Čitanje objava prijatelja kao najčešću aktivnost navelo je 168 (22,2\%) sudionika, gledanje videosadržaja 95 (12,5\%) sudionika, igranje igara 26 (3,4\%) sudionika, praćenje influencera 18 $(2,4 \%)$ sudionika, objavu sadržaja $4(0,5 \%)$ sudionika, kao i slušanje glazbe. Od ostalih odgovora ističe se gledanje tzv. memea (7 sudionika, 0,92\%).

Na Viberu se sudionici najčešće bave dopisivanjem s drugima, što je kao najčešću aktivnost označilo 466 sudionika (94,9\%). Troje sudionika $(0,6 \%)$ kao najčešću aktivnost navodi čitanje objava prijatelja, dok je ostale ponuđene odgovore (objava sadržaja, gledanje videosadržaja, čitanje vijesti) kao najčešću aktivnost naveo po jedan sudionik $(0,2 \%)$. Praćenje influencera, igranje igara i slušanje glazbe nitko nije odabrao kao odgovor. Od ostalih odgovora, ističe se kako 11 sudionika $(2,2 \%)$ navodi da se Viberom koriste samo za komunikaciju s roditeljima.

Na Pinterestu se sudionici, ako gledamo samo ponuđene odgovore, najčešće bave praćenjem influencera, što kao najčešću aktivnost navodi $106(25,1 \%)$ sudionika. Slijedi čitanje objava prijatelja, koje kao najčešću aktivnost navodi 70 (16,5\%) sudionika. Gledanje videosadržaja kao najčešću aktivnost navodi 34 sudionika (8\%), čitanje vijesti 23 sudionika $(5,4 \%)$, objavu sadržaja 18 sudionika (4,3\%) te dopisivanje s drugima 2 sudionika (0,5\%). Važno je napomenuti da čak 125

1 Vatrice se skupljaju svakodnevnom komunikacijom s nekom osobom ako komunikacija traje barem tri dana bez prekida. 
sudionika (29,55\%) navodi da na Pinterestu gleda slike, pri čemu sudionici nerijetko navode vrstu slika koje gledaju (npr. slike vezane uz modu, slike vezane uz prirodu) ili svrhu zbog koje gledaju slike (npr. traženje inspiracije, traženje DIY² uputa).

$\mathrm{Na}$ Twitteru sudionici najčešće prate influencere, što kao najčešću aktivnost navodi 128 sudionika (53,8\%). Slijedi čitanje vijesti, koje kao najčešću aktivnost navodi 49 (20,6\%) sudionika. Čitanje objava prijatelja kao najčešću aktivnost navodi 25 (10,5\%) sudionika, objavu sadržaja 11 $(4,6 \%)$ sudionika, dopisivanje s drugima $7(2,9 \%)$ sudionika te gledanje videosadržaja 5 (2\%) sudionika. Niti jedan sudionik ne navodi da se Twitterom koristi za slušanje glazbe ili igranje igara. Od ostalih se odgovora ništa posebno ne ističe, već sudionici navode osobe koje prate.

Na Tumblru se sudionici najčešće bave čitanjem objava prijatelja, što je kao najčešću aktivnost navelo 35 (29,7\%) sudionika. Slijedi praćenje influencera, što je kao najčešću aktivnost navelo 30 (25,4\%) sudionika. Objavu sadržaja kao najčešću aktivnost odabralo je 18 (15,3\%) sudionika, gledanje videosadržaja 9 (7,6\%) sudionika, dopisivanje s drugima $3(2,5 \%)$ sudionika te čitanje vijesti $3(2,5 \%)$ sudionika. Ni jedna osoba nije navela slušanje glazbe ili igranje igara kao najčešću aktivnost. Od ostalih objava ističe se gledanje slika (5 sudionika, 4,2\%), što se vjerojatno spontano pojavilo kao zasebna kategorija odgovora budući da sudionici prate osobe koje nisu ni influenceri ni njihovi prijatelji ili prate stranice.

Na ASKfm-u sudionici se najčešće bave dopisivanjem s drugima, što kao najčešću aktivnost navodi 4 sudionika (30,8\%). Slijedi čitanje objava prijatelja, što kao najčešću aktivnost navodi 3 sudionika (23,1\%). Objavu sadržaja kao najčešću aktivnost navodi jedan sudionik (7,7\%). Od ostalih odgovora ističe se odgovaranje na pitanja, što navodi 3 sudionika $(23,1 \%)$.

Na Vimeu se sudionici najčešće bave gledanjem videosadržaja, što kao najčešću aktivnost navodi $6(85,7 \%)$ sudionika. Jedan sudionik (14,3\%) navodi dopisivanje s drugima kao najčešću aktivnost na Vimeu.

Kao najčešće korištenu mrežu najveći broj sudionika, njih 887 (49,4\%) ističe Instagram. Slijedi YouTube koji ističe 363 sudionika (20,2\%). WhatsApp kao najčešće korištenu mrežu navodi 249 sudionika (13,9\%), Snapchat 199 (11,1\%), Facebook Messenger 42 (2,3\%), Twitter 13 (0,7\%), Facebook $9(0,5 \%)$, Pinterest $6(0,3 \%)$, Discord $4(0,2 \%)$, Reddit $4(0,2 \%)$ te Viber i Tumblr po 3 sudionika $(0,2 \%)$. Ostale mreže navode se jednom $(0,1 \%)$. Neki sudionici navode da postoje dvije mreže koje najčešće koriste te nisu u mogućnosti izdvojiti samo jednu.

Kao razlog korištenja društvenim mrežama najviše sudionika, njih 1625 (90,6\%), navodi komunikaciju s prijateljima koje poznaju uživo. Slijede zabava i opuštanje s 1469 sudionika (81,9\%), saznavanje informacija o temama koje zanimaju tu osobu s 1226 sudionika (68,3\%), održavanje kontakata s prijateljima i/ili članovima obitelji koji žive daleko s 1147 sudionika (63,9\%), saznavanje događanja u državi i svijetu s 937 sudionika (52,2\%), lakše praćenje događaja u životu prijatelja s 867 sudionika (48,3\%), lakše obavljanje domaće zadaće i/ili učenje sa 781 sudionikom (43,5\%), upoznavanje novih ljudi s 555 sudionika (30,9\%) te komunikacija s prijateljima koje ne poznaju uživo s 452 sudionika (25,2\%). Od ostalih odgovora ističe se gledanje meme-ova s 5 sudionika $(0,3 \%)$.

2 DIY (engl. Do it yourself) termin je koji označava "učini / uradi sam“ metodu prema kojoj ljudi mogu izraditi razne (često kreativne) stvari prateći korake i upute koje postave druge osobe na nekoj od društvenih mreža ili platforma (npr. YouTubeu). 
Najveći broj sudionika, njih 403 (22,5\%), otvorilo je prvi profil na društvenoj mreži s 12 godina. Njih 337 (18,8\%) otvorilo je prvi profil s 13 godina, njih 296 (16,5\%) s 10 godina, njih 261 (14,5\%) s 11 godina (te 1 sudionik s 11,5), njih 159 (8,9\%) s 14 godina, njih 113 (6,3\%) s 9 godina, njih 65 (3,6\%) s 8 godina, njih 57 (3,2\%) s 15 godina, njih 41 (2,3\%) sa 7 godina (te jedan sudionik sa 7,5), njih $17(0,9 \%)$ sa 16 godina, njih $13(0,7 \%)$ sa 6 godina te njih $5(0,2 \%)$ s 5 godina. Ostali su odgovori slabije zastupljeni (do 3 sudionika), međutim nisu uzeti kao nemogući (npr. 1 godina) budući da postoje društvene mreže specifično usmjerene na malu djecu (npr. YouTube Kids). Pojedini sudionici navode u kojoj su godini otvorili prvu društvenu mrežu (npr. 2009., 2011.), no budući da nemamo podatke o mjesecu rođenja sudionika, nije pokušavano računanje dobi tih sudionika u godini koju su naveli. Međutim, ti sudionici nisu izostavljeni iz ostatka obrade.

Najveći broj sudionika, njih 1235 (68,8\%) navodi da je prva društvena mreža na kojoj su otvorili profil bila Facebook. Slijede: WhatsApp sa 165 (9,2\%) sudionika, Instagram sa 156 (8,7\%) sudionika, YouTube sa 101 (5,6\%) sudionikom, Viber sa 100 (5,6\%) sudionika, Snapchat sa 16 (0,9\%) sudionika, ASKfm sa $7(0,4 \%)$ sudionika, Facebook Messenger s $3(0,2 \%)$ sudionika, Tumblr i Twitter s po $2(0,1 \%)$ sudionika te ostale mreže (Edmodo, Gmail, We Heart It) s po $1(0,1 \%)$ sudionikom.

Većini sudionika - 1390 (77,5\%) nitko drugi nije otvorio i uređivao profil. Kod onih kojima jesu, u najvećem broju slučajeva, 192 (47,5\%) bili su to roditelji. Slijede braća ili sestre s 93 slučaja (23\%), prijatelji s 82 slučaja (20,3\%), teta sa 6 slučajeva $(1,5 \%)$ te sestrična s 3 slučaja $(0,7 \%)$. Ostale se osobe javljaju po jedanput $(0,2 \%)$, a sadrže različite odgovore (npr. rođak, mamina prijateljica, strina, ujak, nepoznanici, ljudi koji su me zezali).

Prema čestoći korištenja društvenim mrežama, najviše sudionika, njih 759 (42,3\%) navodi da se njima koristi od 1 do 3 sata dnevno. Nakon toga, 559 sudionika $(31,2 \%)$ navodi da se društvenim mrežama koristi od 3 do 5 sati, 224 sudionika (12,5\%) koristi se od 5 do 7 sati, 140 sudionika (7,8\%) koristi se manje od 1 sat, 69 sudionika (3,8\%) koristi se od 7 do 9 sati, a 43 sudionika $(2,4 \%)$ koristi se društvenim mrežama više od 9 sati dnevno. Prema čestoći provjeravanja notifikacija, najveći broj sudionika, njih 867 (48,3\%) provjeri notifikaciju odmah čim im stigne. Njih 500 (27,9\%) provjerava notifikacije nekoliko puta dnevno, njih 373 (20,8\%) notifikacije provjerava stalno, bez obzira je li notifikacija stigla ili nije, a njih 54 (3\%) notifikacije provjerava jednom dnevno ili rjeđe.

S osobom s kojom su se upoznali online dopisivalo se $68,2 \%$ sudionika. S tvrdnjom da imaju više prijatelja online nego uživo složilo se 12,5\% sudionika. Najveći broj sudionika, njih 60,8\%, ne smatra nikoga od svojih online prijatelja pravim prijateljima, njih $34,5 \%$ smatra neke od svojih online prijatelja pravim prijateljima, 4,3\% smatra većinu svojih online prijatelja pravim prijateljima, a $0,4 \%$ smatra sve svoje online prijatelje pravim prijateljima. Sadašnjeg ili bivšeg partnera putem društvenih mreža upoznalo je $12,8 \%$ sudionika. $65,9 \%$ adolescenata navodi da nije otišlo na susret s osobom koju su upoznali putem društvenih mreža, dok $34,1 \%$ iznosi da je barem jednom u životu otišlo na susret s osobom koju prije nisu poznavali, a upoznali su je putem neke društvene mreže. 


\section{RASPRAVA}

Rezultati su pokazali da je najšire korištena društvena mreža YouTube (najveći broj sudionika koristi se njom), a nakon nje slijede: Instagram, WhatsApp i Snapchat. Pokazalo se i da se navedenim društvenim mrežama koristi više od dvije trećine sudionika, dok se manje od pola sudionika koristi Facebookom. Navedeni rezultati potvrđuju rezultate istraživanja koji također govore da se dio adolescenata i dalje koristi Facebookom, ali u većoj mjeri imaju profile na drugim mrežama (NORC at the University of Chicago, 2017, Smahel i sur., 2020). Ostalim spomenutim društvenim mrežama koristi se puno manje adolescenata, od tek nekoliko sudionika pa do jedne petine onih uključenih u istraživanje, što bi moglo odražavati specifične interese pojedinaca koji se njima koriste. Što se tiče frekvencije korištenja, polovina adolescenata najčešće se koristi Instagramom, petina se najčešće koristi YouTubeom, a otprilike desetina navodi WhatsApp i Snapchat, što je također u skladu s ranije dobivenim podatcima iz literature (Ciboci i sur., 2020). U odnosu na to istraživanje (Ciboci i sur., 2020)., Facebookom se prema učestalosti korištenja očekivano manje služe, odnosno s prvog je pao na šesto mjesto.

Najveći broj sudionika ima jedan profil na većini mreža, no važno je razmotriti i što kažu podatci o broju profila na različitim društvenim mrežama. Istraživanja su pokazala da velik dio adolescenata ima više profila na društvenim mrežama (Anderson i Jiang, 2018 Smith, Purcell, Zickuhr i Rainie, 2011; Ciboci i sur., 2020), a prosječno imaju nešto više od dva profila (Rattinger, 2017). Ipak, u većini istraživanja podatci su prikupljani tako da se adolescente pitalo na kojim mrežama imaju korisnički račun, što ne daje informaciju o tome imaju li samo po jedan profil na više različitih mreža ili pak imaju i više profila na istoj mreži. Naši podatci upućuju na to da vrijedi i jedno i drugo. Točnije, gotovo svi adolescenti imaju profil na više društvenih mreža, ali iz rezultata je vidljivo i da dio njih ima više profila na istoj društvenoj mreži, stoga se postavlja pitanje zbog čega otvaraju višestruke profile na jednoj mreži. Kao što je navedeno u rezultatima, najveći raspon broja profila vidljiv je u korištenju Instagramom. U odnosu na ostale mreže, gdje u prosjeku manji postotak djece ima više profila, na Instagramu čak $48,4 \%$ sudionika ima dva ili više profila. Objašnjenje tih rezultata moglo bi biti povezano s načinom na koji određena društvena mreža funkcionira i kako je zamišljena za korištenje. Naime, ako osoba želi na Facebooku napraviti stranicu na kojoj će kreirati neki sadržaj, to može napraviti u okviru svojega postojećeg korisničkog računa, no ako želi nešto slično napraviti na YouTubeu, mora napraviti novi račun, odnosno YouTube kanal, što povećava vjerojatnost da će na YouTubeu veći postotak korisnika imati više kanala. Također, slična pravila kao i na YouTubeu vrijede i na Instagramu. Dodatno moguće objašnjenje mogu biti i lažni profili koje adolescenti otvaraju, a oni su učestali upravo na Instagramu gdje se zovu "Finstagram" ili

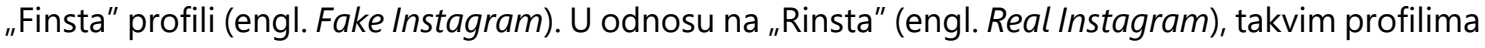
se koriste kao mjestom na kojemu manji broj bliskih prijatelja može vidjeti sadržaj koji osoba dijeli, a u pravilu na njima dijeli sadržaj koji je privatan, šaljiv ili jednostavno nije odraz slike koju korisnik želi ostaviti pred puno ljudi, odnosno pratitelja (Dewar, Islam, Resor, i Salehi, 2019; Kang i Wei, 2020). Adolescenti se koriste tim profilima da bi razvijali individualni identitet (Wiederhold, 2018), odnosno oni im služe kao mjesto na kojemu kreiraju ili prate sadržaje povezane s nekim njihovim usko određenim interesima. Uz navedeno, dodatni profili mogu im služiti i da bi od roditelja skrili neke neželjene sadržaje, a postoji rizik i da je kod dijela adolescenata korištenje takvim profilima povezano s elektroničkim nasiljem koje je učestalije ako je osoba anonimna i njezin profil ne otkriva 
identitet, što bi trebalo provjeriti u budućim istraživanjima. Naposljetku, rezultati pokazuju da tek neznatan broj sudionika ima više profila na aplikacijama za dopisivanje poput WhatsAppa, Vibera, Snapchata i Facebook Messengera, što je očekivano i može se objasniti činjenicom da su takve aplikacije u pravilu vezane uz jedan uređaj, odnosno pametni telefon.

U radu su analizirane i aktivnosti na pojedinim društvenim mrežama. Istraživanja pokazuju da adolescenti vrijeme na internetu najviše provode gledajući videouratke, slušajući glazbu, pretražujući informacije za učenje li školsku zadaću, čitajući vijesti, a kada se gleda interakcija s drugima, najčešće se dopisuju putem aplikacija, razgovaraju s prijateljima i članovima obitelji, posjećuju stranice društvenih mreža te igraju online igre (Smahel i sur., 2020; Ciboci i sur.; 2020, Vejmelka, Strabić, i Jazvo, 2017). lako su u ovom istraživanju ispitane aktivnosti na društvenim mrežama, a ne na internetu općenito, rezultati pokazuju slične zaključke. Očekivano, pokazalo se da se aplikacije za dopisivanje dominantno koriste samo za tu svrhu, a gotovo uopće ne na ostale načine. Zatim, YouTube je karakterističan po videosadržajima u okviru kojih adolescenti gledaju glazbene spotove, objave influencera, a tamo prate i kanale na kojima se drugi korisnici snimaju u igranju videoigara. Zatim, Instagram i YouTube aplikacije su putem kojih najveći broj adolescenata prati influencere, što je aktivnost koju puno adolescenata navodi kao jednu od učestalijih i na ostalim društvenim mrežama. S obzirom na to da je praćenje influencera popularno među adolescentima (Ofcom, 2017), a i naši rezultati upozoravaju na to, potrebno je dodatno istražiti kakav utjecaj to može imati na njih. Primjerice, pokazalo se da adolescenti traže preporuke influencera za proizvode koje žele kupiti (Thomasius, 2018), ali i da, prateći influencere, mogu vidjeti sadržaje vezane uz konzumiranje alkoholnih pića pa time biti pod većim rizikom za prekomjerno uživanje alkohola (Hendriks, Wilmsen, Van Dalen i Gebhardt, 2020).

Većina djece počela se koristiti društvenim mrežama tako da su napravili profil na Facebooku, a tek rijetki od njih prvi profil napravili su na WhatsAppu i Instagramu, trenutno popularnijim mrežama među njima. Facebook se pokazao manje korištenom društvenom mrežom, premda se i dalje određeni dio mladih koristi njom radi "grupa" povezanih za obrazovanje (npr. grupe za razred, fakultet i sl.) Tri četvrtine djece otvorilo je profile na društvenim mrežama bez pomoći odrasle osobe, što otvara pitanje u kojoj su mjeri pritom imali potrebne informacije i smjernice o sigurnosti i zaštiti računa. Treba imati na umu da vještina korištenja digitalnim alatima kod djece ne mora podrazumijevati i stvarnu informatičku pismenost i sposobnost kritičkog mišljenja (Babić $i$ Irović, 2011). Djeca, kojoj su u tome pomogli odrasli, navode da su to najčešće bili roditelji, a nešto manje braća, sestre ili prijatelji. Prema jednom istraživanju, prosječna dob djece pri pristupanju društvenim mrežama je 10 godina (Rattinger, 2017). U ovom istraživanju najveći broj djece otvorio je profil s 12 godina, a čak dvije trećine sudionika otvorilo je profil prije trinaeste godine, što je na većini mreža minimalna dob za pristupanje. To znači da je većina djece skrivala informaciju o stvarnoj dobi jer inače ne bi mogli otvoriti profil, a ako uzmemo u obzir i da su to u pravilu činili bez nadzora odraslih, može se zaključiti da je stupanje u svijet društvenih mreža aktivnost koju djeca provode bez primjerena nadzora.

U skladu s očekivanjima, adolescenti provode značajno puno vremena u danu koristeći se društvenim mrežama. Primjerice, adolescenti srednjoškolske dobi na internetu provode prosječno 3-4 sata dnevno (Smahel i sur., 2020), a slični rezultati, koji upućuju na to da adolescenti provode 2 do 3 sata dnevno koristeći se internetom, dobiveni su i na hrvatskom uzorku (Vejmelka i sur., 
2017). Nadalje, gotovo svako četvrto dijete provodi više od četiri sata dnevno na internetu tijekom radnog tjedna, a tijekom vikenda više od jedne trećine djece (Ciboci i sur., 2020). lako naši podatci govore o korištenju društvenim mrežama, a ne internetom općenito, i dalje upozoravaju na enormno vrijeme provedeno u tim aktivnostima. Oko $40 \%$ sudionika procjenjuje da se dnevno koristi društvenim mrežama do tri sata u danu, što bi ulazilo u okvire preporuka stručnjaka, vezane uz korištenje medijskim sadržajima, samo ako se uz društvene mreže ne bi koristili nikakvim drugim sadržajima poput gledanja televizije ili igranja videoigara. Važan je podatak da pola sudionika više od tri sata dnevno provodi koristeći se društvenim mrežama, posebno ako se uzme u obzir da neki od njih provode sedam, osam ili čak devet i više sati dnevno u takvim aktivnostima. Osim vremenske uključenosti, znakovit je rezultat da pola sudionika provjerava obavijesti dobivene putem društvenih mreža odmah nakon dolaska. Ti rezultati, kao i slični rezultati koji govore o neprekinutoj uključenosti dijela djece u društvene mreže (Rattinger, 2017), navode na pretpostavku o tome da je njihova uključenost u aktivnosti na društvenim mrežama nešto što se odvija bilo kada i može prekinuti različite druge aktivnosti kojima se bave, poput učenja, praćenja nastave ili komunikacije uživo s članovima obitelji i prijateljima.

Pokazalo se da je dominantan aspekt korištenja društvenim mrežama sudionicima komunikacija s prijateljima, kao i održavanje kontakata s bliskim osobama koje žive daleko te praćenje događaja u životu bliskih osoba, što je očekivano. Naime, kontakti i komunikacija s prijateljima te uključenost u njihove živote pokazali su se bitnim razlozima za korištenje društvenim mrežama i u drugim istraživanjima (Pregrad, Tomić Latinac, Mikulić i Šeparović, 2010; Rattinger, 2017; Ciboci i sur., 2020). Takvi se rezultati mogu povezati i s dobi sudionika. Razvojno je očekivano da se u adolescenciji mladi sve više okreću vršnjacima, a u skladu s tim žele na više načina održavati kontakt s njima, pa tako i putem interneta i društvenih mreža. Može se reći da putem društvenih mreža na virtualan način nadoknađuju susrete s vršnjacima uživo (Boyd, 2014). Osim komunikacijskog aspekta, sudionici su kao važne razloge korištenja društvenim mrežama naveli i zabavu, informiranje o sadržajima i temama koje ih zanimaju te učenje, što je u skladu s ranijim istraživanjima (Smahel i sur., 2020; Ciboci i sur., 2020) i govori o doživljavanju društvenih mreža kao mjesta za razonodu, ali i učenje. Naposljetku, društvene mreže neki sudionici doživljavaju kao način upoznavanja ljudi i komuniciranje s osobama koje ne poznaju uživo, što može, ali i ne mora biti rizično. S jedne strane, ako se komunikacija putem društvenih mreža shvati kao nadopuna komunikacije uživo, razumljivo je da adolescenti teže upoznavanju novih ljudi i širenju socijalne mreže. Tako mogu upoznati osobe koje dijele slične interese, od kojih mogu naučiti nešto novo i koji im mogu biti podrška (Smahel i sur., 2020; Dedkova, 2015). No, razumijevanje takvih interesa i ponašanja adolescenata ne smije značiti i zanemarivanje brige o sigurnosnim aspektima i rizicima koje može donijeti komunikacija s nepoznatima putem interneta (Smahel i sur., 2020).

Zabrinjavajući rezultati dobivaju se na pitanjima o dopisivanju i nalaženju s osobom koju su upoznali online. Naime, gotovo $70 \%$ adolescenata u ovom istraživanju navodi da se dopisivalo s osobom koju su upoznali online, a više od $30 \%$ se s osobom koju su upoznali putem društvenih mreža upoznalo na dogovorenom susretu. Wurtele i Kenny (2016) upozoravaju na rizik kod adolescenata da se upuštaju u susrete licem u lice nakon ostvarivanja komunikacije putem elektroničkih uređaja. Povećanu vjerojatnost uključivanja u rizična ponašanja kod adolescenata potvrđuju i rezultati istraživanja Fansher i Randa (2018) koji navode da 1 od 20 mladih osoba donese odluku da će 
se upoznati s osobom koju su upoznali putem interneta u prva 24 sata od inicijalnog kontakta na elektroničkim uređajima. Istraživanjem EU Kids Online dobiveni su podatci o tome da $9 \%$ djece u dobi od 9 do 16 godina odlazi na susret "licem u lice" nakon upoznavanja putem društvenih mreža (Livingstone i Smith, 2014). Navedeno bi potencijalno značilo da, s obzirom na uzorak u ovom istraživanju, broj mladih koji odlaze na upoznavanje osobe koju su upoznali online raste s dobi, što je naročito problematično uzevši u obzir ranije navedene sklonosti adolescenata za upuštanje u rizična ponašanja. Dodatno treba naglasiti da je u Ujedinjenom Kraljevstvu još 2006. godine $2 \%$ svih zabilježenih slučajeva seksualnog zlostavljanja djece bilo posredovano upravo putem elektroničkih uređaja, a s obzirom na sve veću raširenost digitalne tehnologije među djecom i mladima, ta brojka bi u današnje vrijeme mogla biti znatno veća (Gallagher, Fraser, Christmann i Hodgson, 2006).

U kontekstu ograničenja ovog istraživanja treba napomenuti samu metodologiju, odnosno nacrt istraživanja i prirodu prikupljenih podataka. Također, jedan od nedostataka provedenog istraživanja je i „zastarjelost” podataka koja se odnosi na dinamiku u korištenju društvenim mrežama kod djece i mladih što je razvidno i na primjeru društvene mreže TikTok koja je u kratkom vremenu stekla popularnost među mladima u gotovo manje od godinu dana. Slijedom toga, bilo bi važno kontinuirano provoditi istraživanja o preferencijama mladih s obzirom na aktualne društvene mreže. Također, bilo bi od iznimne koristi razviti metodologiju koja omogućuje praćenje i adekvatno testiranje trendova, odnosno konstruirati longitudinalne nacrte istraživanja pomoću kojih bi se osiguralo ispitivanje istih sudionika u više različitih točaka mjerenja da bi se upravo dobio uvid u promjene u trendovima korištenja društvenim mrežama, ali i eventualne promjene u preferencijama društvenih mreža s obzirom na dob sudionika. Isto tako, u budućim istraživanjima bilo bi korisno uz TikTok pokriti i još neke društvene mreže, odnosno socijalne medije orijentirane na šaljive slike i fotografije (poput 9gaga).

Glavni doprinos ovog istraživanja odnosi se na broj sudionika uključenih u istraživanje, kao i na podjednaku zastupljenost sudionika s obzirom na spol, odnosno učenika i učenica. Podatci dobiveni ovim istraživanjem mogu se smatrati uporišnom točkom za praćenje promjena u korištenju društvenim mrežama kod mladih. Narednim analizama iz ranije spomenutoga šireg istraživačkog projekta bilo bi korisno provjeriti trendove u sekstingu među mladima, kao i rizičnim ponašanjima te utvrditi postojanje mogućih povezanosti te potencijalnih rizičnih i zaštitnih čimbenika za uključivanje mladih u rizična online ponašanja na pojedinim društvenim mrežama, ali i općenito.

\section{ZAKLJUČAK}

Ovim istraživanjem izloženi su aktualni trendovi količine i načina provođenja vremena na internetu kod adolescenata srednjoškolskog uzrasta. Određene su društvene mreže u kratkom razdoblju postale vrlo popularne među adolescentima i prednjače kad su u pitanju mladi koji navode da se njima koriste (npr. Instagram, YouTube i Snapchat), dok je kod drugih društvenih mreža, poput Facebooka, koji je donedavno bio vrlo aktualan među mladima, broj mladih koji navode da se njim koriste značajno manji. Društvene mreže postale su jedan od glavnih čimbenika u socijalizaciji mladih, stoga je ovoj temi važno pristupiti multidisiciplinarno. Upravo zbog toga, informacije o zastupljenosti društvenih mreža kod djece i mladih, ali i načinu njihova korištenja daju nam uvid u određivanju smjera prilikom konstruiranja edukacijskih i prevencijskih programa koji bi 
bili interesantni i aktualni mladima. Određen se broj mladih dopisuje putem elektroničkih uređaja s osobom koju ne poznaje, a drugi su se nakon dopisivanja s osobom putem interneta odlučili na upoznavanje licem u lice. Navedeno upućuje i na potrebu za kontinuiranim informiranjem stručnjaka s trendovima korištenih društvenih mreža, ali i postavkama privatnosti da bi se pokušalo preventivno djelovati na negativne aspekte, odnosno posljedice korištenja društvenim mrežama. Isto tako, bilo bi korisno educirati i roditelje koji će pratiti navike djece i mladih, a uz to i ulagati u implementaciju strukturiranih edukacijskih modaliteta rada s djecom i mladima o sigurnom korištenju internetom te potrebi usvajanja kritičkog promišljanja sadržajem u srednjim školama, ali potencijalno i ranije.

\section{LITERATURA}

Anderson, M. i Jiang, J. (2018a). Teens' social media habits and experiences. Pew Research Center, 28. Preuzeto s: https://www.pewresearch.org/internet/2018/11/28/teens-social-media-habits-and-experiences/ (02.06.2020.)

Anderson, M. i Jiang, J. (2018 b). Teens, social media \& technology 2018. Pew Research Center, 31. Preuzeto s: https://www.pewresearch.org/internet/2018/05/31/teens-social-media-technology-2018/ (02.06.2020.)

Babić, N. i Irović, S. (2011). ICT and the new culture of learning/teaching. U N. I. Pak, P. S. Lomasko i T. A. Stepanova (ur.), Krasnojarsk: Krasnojarskii gosudarstvennyi pedagogicheskii universitet im. V. P. Astafjeva (str. 9-13). Krasnojarsk, Ruska Federacija.

Barrense-Dias, Y., Berchtold, A., Surís, J. C. i Akre, C. (2017). Sexting and the definition issue. Journal of Adolescent Health, 61(5), 544-554. https://doi.org/10.1016/j.jadohealth.2017.05.009

Beck, J. S., Beck, A. T., Jolly J. B. i Steer, R. A. (2011). Beckov inventar za djecu i adolescente. Priručnik. Jastrebarsko: Naklada Slap.

Bianchi, D., Morelli, M., Baiocco, R. i Chirumbolo, A. (2018). Psychometric properties of the Sexting Motivations Questionnaire for adolescents and young adults. Rassegna di Psicologia, 33(3), 5-18. https://doi.org/10.4558/8067-01

Ciboci, L., Ćosić Pregrad, I., Kanižaj, I., Potočnik, D. i Vinković D. (2020). Nacionalno istraživanje o sigurnosti djece na internetu HR Kids Online. Društvo za komunikacijsku i medijsku kulturu. Preuzeto s: http://hrkids.online/prez/EUKidsOnlineHRfinal.pdf (02.06.2020.)

Dedkova, L. (2015). Stranger is not always danger: The myth and reality of meetings with online strangers. U P. Lorentz, D. Smahel, M. Metykova i M.F. Wright (ur.), Living in the digital age: Self-presentation, networking, playing, and participating in politics (str. 78-94). Muni Press.

Dewar, S., Islam, S., Resor, E. i Salehi, N. (2019). Finsta: Creating" Fake" Spaces for Authentic Performance. U Extended Abstracts of the 2019 CHI Conference on Human Factors in Computing Systems (str. 1-6).

Döring, N. (2014). Consensual sexting among adolescents: Risk prevention through abstinence education or safer sexting? Cyberpsychology: Journal of Psychosocial Research on 18 Cyberspace, 8(1). Preuzeto s: https://cyberpsychology.eu/article/view/4303/3352 (02.06.2020.)

Drouin, M. i Tobin, E. (2014). Unwanted but consensual sexting among young adults: Relations with attachment and sexual motivations. Computers in Human Behavior, 31, 412-418. https:// doi.org/10.1016/j.chb.2013.11.001 
Državni zavod za statistiku Republike Hrvatske (2019). Primjena informacijskih i komunikacijskih tehnologija (IKT) u kućanstvima i kod pojedinaca u 2019., prvi rezultati. Preuzeto s: https://www. dzs.hr/Hrv_Eng/publication/2019/02-03-02_01_2019.htm (20.10.2020.)

Eleuteri, S., Saladino, V. i Verrastro, V. (2017). Identity, relationships, sexuality, and risky behaviors of adolescents in the context of social media. Sexual and Relationship Therapy, 32(3-4), 354-365. https://doi.org/10.1080/14681994.2017.1397953

Eurostat (2019). Are you using social networks? Preuzeto s: https://ec.europa.eu/eurostat/web/products-eurostat-news/-/EDN-20190629-1 (20.10.2020.)

Eurostat (2020). Being young in Europe today - digital world. Preuzeto s: https://ec.europa.eu/eurostat/statistics-explained/pdfscache/39761.pdf (20.10.2020.)

Gallagher, B., Christmann, K., Fraser, C. i Hodgson, B. (2006). International and Internet Child Sexual Abuse and Exploitation: Research Report Centre for Applied Childhood Studies and The Nuffield Foundation. Preuzeto s: https://pure.hud.ac.uk/en/publications/international-and-internet-child-sexual-abuse-and-exploitation-re (20.10.2020.)

Hendriks, H., Wilmsen, D., Van Dalen, W. i Gebhardt, W. A. (2020). Picture me drinking: alcohol-related posts by instagram influencers popular among adolescents and young adults. Frontiers in psychology, 10, 2991. https://doi.org/10.3389/fpsyg.2019.02991

Kang, J. i Wei, L. (2020). Let me be at my funniest: Instagram users' motivations for using Finsta (aka, fake Instagram). The Social Science Journal, 57(1), 58-71. https://doi.org/10.1016/j.soscij.2018.12.005

Kosenko, K., Luurs, G. i Binder, A. R. (2017). Sexting and sexual behavior, 2011-2015: A critical review and meta-analysis of a growing literature. Journal of computer-mediated communication, 22(3), 141-160. https://doi.org/10.1111/jcc4.12187

Kušić, S. (2010). Online društvene mreže i društveno umrežavanje kod učenika osnovne škole: navike Facebook generacije. Život i škola: časopis za teoriju i praksu odgoja i obrazovanja, 56(24), 103-125.

Lenhart, A., Madden, M., Smith, A., Purcell, K., Zickuhr, K. i Rainie, L. (2011). Teens, Kindness and Cruelty on Social Network Sites: How American Teens Navigate the New World of "Digital Citizenship". Pew Internet i American Life Project. Preuzeto s: https://www.pewresearch.org/internet/2011/11/09/ teens-kindness-and-cruelty-on-social-network-sites/ (20.10.2020.)

Livingstone, S. i Smith, P. K. (2014). Annual research review: Harms experienced by child users of online and mobile technologies: The nature, prevalence and management of sexual and aggressive risks in the digital age. Journal of child psychology and psychiatry, 55(6), 635-654. https:// doi.org/10.1111/jcpp. 12197

NORC at the University of Chicago (2017). Instagram and Snapchat are the most popular social networks for teens; black teens are most active on social media, messaging apps. The Associated Press-NORC Center for Public Affairs Research. Preuzeto s: http://apnorc.org/projects/ pages/html\%20reports/instagram-and-snapchat-are-most-popular-social-networks-for-teens. aspx (04.04.2020.)

Ofcom (2017). Children and Parents: Media Use and Attitudes Report. Preuzeto s: https://www. ofcom.org.uk/_data/assets/pdf_file/0020/108182/children-parents-media-use-attitudes-2017. $p d f(04.04 .2020$.)

Orosz, G., Tóth-Király, I. i Bőthe, B. (2016). Four facets of Facebook intensity-the development of the multidimensional Facebook intensity scale. Personality and Individual Differences, 100, 95 104. https://doi.org/10.1016/j.paid.2015.11.038 
Pregrad, J., Tomić Latinac, M., Mikulić, M. i Šeparović, N. (2010). Iskustva i stavovi djece, roditelja i učitelja prema elektroničkim medijima - izvještaj o rezultatima istraživanja provedenog među djecom, učiteljima i roditeljima u sklopu programa prevencije elektroničkog nasilja "Prekini lanac!". Zagreb: Unicef. Preuzeto s: https://www.unicef.hr/wp-content/uploads/2015/09//zvjestaj_-Iskustva_i_stavovi_djece_roditelja_i_ucitelja_prema_elektronickim_medijima.pdf (20.10.2020.)

Rattinger, M. (2017). Aktivnosti i društvene mreže u slobodnom vremenu mlađih tinejdžera. Školski vjesnik: časopis za pedagogijsku teoriju i praksu, 66(2), 222-237.

Ružić, V. i Matešić, K. (2015). BYI-II - Beckovi inventari za mlade - drugo izdanje za djecu i adolescente - provjera valjanosti instrumenta u Republici Hrvatskoj. Klinička psihologija, 8(1), 49-61.

Smahel, D., Machackova, H., Mascheroni, G., Dedkova, L., Staksrud, E., Ólafsson, K., Livingstone, S. i Hasebrink, U. (2020). EU Kids Online 2020: Survey results from 19 countries. EU Kids Online. https://doi.org/10.21953/lse.47fdeqj01ofo

Thomasius, R. (2018). Whatsapp, Instagram and Co. - so Addictive is Social Media. Preuzeto s: https://www.saferinternet.at/fileadmin/redakteure/Footer/Studien/dak-studie-social-medianutzung-1968596.pdf (26.08.2019.)

Vannucci, A., Simpson, E. G., Gagnon, S. i Ohannessian, C. M. (2020). Social media use and risky behaviors in adolescents: a meta-analysis. Journal of Adolescence, 79, 258-274. https://doi.org/10.1016/j.adolescence.2020.01.014

Vejmelka, L., Strabić, N. i Jazvo, M. (2017). Online aktivnosti i rizična ponašanja adolescenata u virtualnom okruženju. Društvena istraživanja, 26(1), 59-78. https://doi.org/10.5559/di.26.1.04

Wiederhold B. K. (2018). The Tenuous Relationship Between Instagram and Teen Self-Identity. Cyberpsychology, behavior and social networking, 21(4), 215-216. https://doi.org/10.1089/cyber.2018.29108.bkw

Yonker, L. M., Zan, S., Scirica, C. V., Jethwani, K. i Kinane, T. B. (2015). "Friending" teens: systematic review of social media in adolescent and young adult health care. Journal of medical Internet research, 17(1), e4. https://doi.org/10.2196/jmir.3692 


\title{
ANALYSIS OF CURRENT TRENDS IN USE OF SOCIAL NETWORKS AMONG FIRST AND THIRD GRADE STUDENTS OF SECONDARY SCHOOLS IN CROATIA
}

\author{
Gordana Buljan Flander \\ Ella Selak Bagarić \\ Krešimir Prijatelj \\ Mirna Čagalj Farkas
}

Child and Youth Protection Center of Zagreb

\begin{abstract}
Since growing up nowadays almost certainly involves the daily use of modern technologies, it is important to examine how and in what ways young people spend time online and using social networks. The aim of the study was to examine the general habits of internet and social media use among adolescents of high school age in the Republic of Croatia ( $N=$ 1806). Several factors of time spent on the internet and social networks were examined through the Google Forms platform by an online questionnaire designed for the purpose of this research. The findings indicate activities of adolescents across specific social networks, as well as adolescent-related factors in the context of online activities. The findings show that social network preferences in adolescents have changed over time but also suggest a tendency to engage in risky behaviors such as meeting or corresponding with strangers. Findings point to the need for continuous training of experts and parents who will keep track of habits of children and young people, as well as the implementation of structured modalities of work with children and young people regarding safe internet use.
\end{abstract}

Keywords: social networks, internet, adolescents, habits, electronic devices 